for Scotland that a grant not exceeding $£ 9,800$ should be made available (after taking into account any receipts from other sources) from the Development Fund to enable necessary building extensions to be undertaken. In view of the economic importance of grass sickness, it became clear to the Department of Agriculture for Scotland and the Agricultural Research Council that further extension and intensification of the research into the cause and prevention of this disease are necessary, and the Treasury has sanctioned an appropriation from the Development Fund to the Department of Agriculture for Scotland of a sum not exceeding $£ 3,200$ to meet the expenditure for extended work on this disease during the current financial year. Several contributions towards the cost of grass sickness investigation have been received from outside sources, notably that from the Racecourse Betting Control Board, which has granted $£ 1,000$ for the work at Moredun during 1937. While the cause of this fatal disease, which is reported to have killed 1,200-1,500 horses last summer and is by no means confined to Scotland, is suspected to be due to poisoning developed in the intestine by certain bacteria, taken in on grass or in some other way during feeding, this theory, though promising, is not yet proved. A large-scale vaccination trial, which is being made after careful preliminary experiments, is intended as a further test of this theory.

\section{General Science and Education for Citizenship}

Prof. Lancelot Hogren's address on "The Teaching of Science in the Education of the Citizen", delivered at a conference of higher education members of the National Union of Teachers on December 30 has now been made available in pamphlet form (London: National Union of Teachers). There is much that is controversial in the address, and the Union is careful to disclaim responsibility for its views and opinions; but its provocativeness is stimulating. It starts from the position that the social task of modern education is "to implement the age of plenty. To do it we have to make the record of scientific discovery an open Bible". In the teaching of science should be epitomized the drama of human achievement, and at each stage the question "Did this or that principle, this or that theory, help mankind to lift this or that stone in the building of the temple of plenty ?" will serve to discriminate between the essential and the non-essential constituents of any proposed curriculum and to reconcile the competing claims of specialists. But how about preparation for passing examinations designed by specialists without regard to the requirements of intelligent citizenship ? Will students taught on these principles be able to cope with them ? Will not those who are themselves destined to become specialists suffer ?

To these questions, Prof. Hogben gives answers based on his own teaching experience. The keen interest aroused by the approach to science as a social venture, and the framework of important facts and comprehensive principles provided by it make the memorizing of the less vital facts needed for passing examinations an easy matter and make a sound basis for later specialization. A fatal error in the teaching of science is the presentation of principles without regard to a sufficient background of relevant information. Prof. Hogben finds an illustration of this in present methods of teaching electricity and magnetism. He advocates a greatly extended use of films in the teaching of science. The cinema, he says, can bridge the gulf which now separates people who have a good visual imagination from those who have not.

\section{New Power Station on the Rhine}

IN the Escher-Wyss News of December, published by the well-known engineering works at Zurich, a complete description is given of the Albbruck-Dogern Power Station on the Rhine. The Rhine, which historically has played an outstanding part among the rivers of Europe, has gained appreciably in commercial importance during the last ten years. Formerly its importance depended on navigation, which gradually spread up the river from the Niederrhein to Basle, now a port handling more than $2 \cdot 2$ million tons annually. During the last ten years the utilization of the water-power has proceeded in the opposite direction from the Upper Rhine down the Rhine valley. The part of the river of greatest interest as regards power generation is that lying between the Lake of Constance and Strasbourg. This stretch extends about a hundred miles, and if we exclude the sudden drop at the Rhine Falls, the gradient is about 1 in a 1,000. There are now eight, including the latest, the Albbruck-Dogern, low head waterpower stations erected along this stretch of the Rhine.

For the complete utilization of the Rhine six further stations are projected. The installed output of all the stations together will amount to approximately one million horse power, and the average yearly generation of electricity will be about 5,000 million kilowatt hours. With the exception of the French station at Kembs, all the stations have Escher-Wyss water turbines. The new station at Albbruck-Dogern utilizes the flow from the head of the Rhine to the lower course of the Aare as far as the Klingnau power station. The water supplied by the head race has an average flow of 900 cubic metres per second. It is utilized in three vertical shaft turbines each of which is capable of developing 37,600 h.p. under a head of 11.5 metres and with a maximum flow of 290 cubic metres per second. The power station is at Albbruck and has a length of 87 metres and a breadth of $29 \cdot 3$ metres. The three sets, each consisting of a water turbine and an electric generator, are arranged in a row at right angles to the canal and 27 metres apart. After passing through a transformer the electric energy is transmitted at 104 kilovolts.

\section{Prepayment Electricity Metres}

THE prepayment meter is, in general, suitable for the user of electricity whose means are small. The advantages are that he pays in small amounts and 
that he has an incentive to check and control running costs. The disadvantages are that he pays slightly more per unit consumed, and the supply is apt to be interrupted at inconvenient times. To the supply company, the advantages are that there is less accounting as there are no bills, there is a reduction in bad debts, and special applications can be used in hotels and boarding houses. On the other hand, the reading and collecting cost is increased and so also is the maintenance. Mention of coin mechanisms in connexion with measuring holy water beg $\mathrm{n}$ about A.D. 200. A history and criticism of various types of 'coin mechanisms' in connexion with electric meters are given in a paper by J. Prince and M. Whitehead read to the Institution of Electrical Engineers on April 2. Most of the difficulties in connexion with these meters, including the prevention of fraudulently tampering with them, have now been overcome. One of the outstanding points which affect the use of coin mechanisms is the psychological reaction of the peoples concerned. According to the authors, there is a definite objection to prepayment in both Canada and the United States. They are not used in Denmark, France and Portugal. A few are in use in Holland, Austria, Switzerland, New Zealand and Italy. Great Britain seems to be the only country in which there is a great demand for prepayment meters; probably because it provides the best means of promoting the use of electricity among people of small means.

\section{Journal of the University of Manchester}

From the University of Manchester we have received a copy of the University's Journal, No. 1, vol. 1, published by the Manchester University Press. In an inaugural message from the chairman of Council, Sir Christopher Needham, the Journal is described as a new venture designed by the Council to meet what it feels to be a responsibility in regard to graduates, to provide news of University interest and information of developments in University policy as well as personal matters. Conversely, an article by Mr. David Cardwell, chairman of Convocation, reminds graduates that active membership of Convocation (which has, since 1915, followed automatically on graduation) affords a means of service whereby the life-long debt they owe to their University may, in some measure, be repaid. The realization of this ideal has been facilitated by the formation of Groups of Convocation formed in Manchester, London, Leeds and Sheffield and contemplated at Oxford, for discussing matters of University interest and such social and other activities as their members may desire. Sir Ernest Simon contributes an article, "A Time for Expansion: the New Buildings and the Future", describing buildings just completed at a cost of $£ 100,000$, others (including a new dental school and hospital and physical chemical research laboratory, swimming bath, etc.) which it is hoped to complete by the end of 1938, and a project, illustrated by an architect's drawing, for further urgently needed developments destined to form with the buildings already mentioned a dignified and impressive quadrangle. Among other contributors to the journal are: Prof. A. H. Gibson (on the Department of Engineering), Prof. Edward Fiddes (on "Some Teachers of Owens College"), Dr. Tyson (on "The Library and its Uses") and Prof. G. H. Thompson (his Ludwig Mond lecture on "Intelligence and Civilisation"). Copies of the Journal will be supplied without charge and on application, to graduates and friends of the University.

\section{Dr. H. L. Richardson}

Dr. H. L. Richardson, of the Chemistry Department, Rothamsted Experimental Station, has been appointed adviser in soils and fertilizers to the National Agricultural Research Bureau, Shaolingwei, Nanking, China. This institution, which was founded in 1931, possesses extensive laboratories and a farm of 400 acres, and has already made great progress in the investigation of crop production, plant diseases, animal production, and crop recording. In addition to conducting experiments at Nanking, it works in close collaboration with the numerous provincial research stations in China. Dr. Richardson received his training at Victoria University College, New Zealand, and the University of London, and joined the Rothamsted staff in 1927. He has been particularly associated with the developments in soils and fertilizers.

\section{Indian Institute of Science}

IT is reported from Bangalore that, at a meeting of the Governing Council of the Indian Institute of Science held on June 1, Sir C. V. Raman decided to sever his connexion with the Institute. The Council proposed that he should continue in the Institute as professor of physics without administrative powers, and suggested the appointment of an interim director to administer the affairs of the Institute pending the appointment of a new director. Sir C. V. Raman declined the offer of the Council and was unwilling to continue as a subordinate to any other director. It was recommended by the Irvine Committee that a registrar should be appointed to relieve the director of administrative duties and to be directly responsible to the Governing Council. Early this year, it was reported that $\mathrm{Mr}$. R. H. Beckett had been appointed registrar of the Institute, but we understand that, though he was offered the post, he did not accept it. We are now informed that the registrar will be Mr. C. E. W. Jones, C.I.E., lately director of public instruction, Central Provinces.

\section{Chemical Engineering Exhibition in Germany}

Announcements have been issued of the meeting in Frankfort-on-Main during the week July 2-11 of the various bodies in Germany concerned with chemical engineering and the holding at the same time of the Eighth Chemical Engineering Exhibition, widely known as the "Achema". At the last Achema Exhibition, held in Cologne in 1934, an impressive picture was given of the high standard of production of chemical engineering plant and apparatus in Germany and the exhibition attracted 49,000 visitors. 